\title{
First report of phytophagous stink bug in chicory crop
}

\author{
Primeiro registro de percevejo fitófago em cultura de almeirão
}

\author{
Diones Krinski ${ }^{I}$
}

- NOTE -

\section{ABSTRACT}

This study reports the first occurrence of the stink bug Edessa meditabunda (F.) (Heteroptera: Pentatomidae) on chicory in Pará State, Brazil (77'45.59"S 55²3’20.99"W). Samples were taken at Florentino Farm, municipality of Novo Progresso from a plot of plants $(5 \mathrm{mx} 1,25 \mathrm{~m})$. Sixty-eight chicory plants were sampled and 1.649 adults, 636 nymphs and 1.012 egg masses were obtained.

Key words: Pentatomidae, Cichorium intybus, insect pest.

\section{RESUMO}

Esta nota relata a primeira ocorrência do percevejo Edessa meditabunda (F.) (Heteroptera: Pentatomidae) na cultura de almeirão, no Estado do Pará (77’45.59"S 55²3’20.99"W). Na Fazenda Florentino, município de Novo Progresso, em um canteiro $(5 \mathrm{mx} 1,25 \mathrm{~m})$, foram coletados percevejos adultos, ninfas e posturas. Em 68 plantas de almeirão, coletaram-se 1.649 adultos, 636 ninfas $e$ 1.012 posturas.

Palavras-chave: Pentatomidae, Cichorium intybus, inseto-praga.

The genus Edessa (Fabricius) has about 260 described species widely distributed in the Neotropical
Region, exhibiting different sizes, colors, and shapes (FERNANDES \& CAMPOS 2011; SILVA et al., 2006). In South America, some species feed on several plants important for the economy (PANIZZI et al., 2000). The species Edessa meditabunda (Fabricius), occurs on several plants including squash, lettuce, cotton, rice, potato, eggplant, beet, boldo, chayote, citrus, pea, tobacco, sunflower, cassava, melon, pepper, chili , soybean, rattlepod and tomato, and may cause economic damage (COSTA \& LINK, 1974; BUZZI \& MIYAZAKI, 1993; LIMA \& RACCA FILHO, 1996; LOURENÇÃO et al., 1999; PANIZZI, 2002; GONÇALVES et al., 2008; GOLIN et al., 2011; KRINSKI et al., 2012; KRINSKI \& PELISSARI, 2012).

According to GONÇALVES et al. (2008), damage caused by $\boldsymbol{E}$. meditabunda may limit the agricultural production, depending on the number of insects that are feeding on the phyto-host and the phenologic structure of the plant used by them. In soybean, for example, this stink bug can cause leaf retention, deformations and decreased the size of the seeds, reduction of oil content and of the germination potential (LOURENÇÃO et al., 1999; GALLO et al., 2002). However, there are no reports of the occurrence

IPrograma de Pós-graduação em Zoologia, Departamento de Zoologia, Setor de Ciências Biológicas, Centro Politécnico, Universidade Federal do Paraná (UFPR), Bairro Jardim das Américas, CP 19020, 81531-980, Curitiba, PR, Brasil. E-mail: diones.krinski@ufpr.br. Autor para correspondência. 
and of the damage that this species of stink bug causes on the culture of chicory.

Chicory, Cichorium intybus L. is a herbaceous plant with annual cycle, belonging to the family Asteraceae (Compositae). It is commonly used in food as salads and the roots can be used dried and grinded as tea, in substitution or in addition to coffee (RYDER, 1998). In Brazil, C. intybus is popularly called chicory, chicory-true, radich and due to the taste of its leaves, is also known as bitter chicory (SANDANIELO \& LUNARDI, 2002).

In contrast to the worldwide distribution of chicory, studies regarding insects that attack this crop are nonexistent. The researchs are usually related to productive characteristics, pharmaceutical properties, and nutritional and biomonitor value (GODOI et al., 2007; AKSOY, 2008; ANDRIOLO, et al., 2008; FAVERI et al., 2009; FALLAH et al., 2011; WANG \& CUI, 2011; among others). Therefore, the aim of this paper is to report the first occurrence of stink bug $\boldsymbol{E}$. meditabunda on chicory (C. intybus).

Samplings of stink bugs were carried during October 2010 on plants of chicory cv. Folha Larga in a vegetable garden from Florentino Farm, located in the municipality of Novo Progresso, Pará State, Brazil (77'45.59"S 55²3’20.99"W). Adults, nymphs, and egg masses were collected from 68 chicory plants. A total of 1.649 adults, 636 nymphs and 1.012 egg masses of E. meditabunda were sampled (Figure 1). Of the total number of egg masses collected, $9.2 \%$ were parasitized by microhimenopterans, $21.4 \%$ hatched, and $69.5 \%$ were not parasitized. The average number of adults, nymphs and egg masses per plant was 24.3, 14.9, and 9.4, respectively. These results suggest that this stink bug may become a primary pest to chicory.

Some studies, such as WELLS \& LOY (1985) report among the advantages of producing the chicory in a protected environment (greenhouse), the reduction in the incidence of insects and other pests on crop, but they do not report any insect pests occurring in this plant. Therefore, the results presented here are interesting, since the Manual of Vegetables Nonconventional (BRASIL, 2010) reports that so far there is no records of insect pests described for $\boldsymbol{C}$. intybus. In this paper, it can be observed that leaves attacked by nymphs of $\boldsymbol{E}$. meditabunda were more wrinkled than those not attacked (Figure 1B). Thus, further studies on the relationship between these stink bugs with the chicory plants are needed in order to understand this insect-plant interactions, and try to check if the presence of $\boldsymbol{E}$. meditabunda causes any damage related to the texture, taste and consequently to the production of $\boldsymbol{C}$. intybus.

\section{ACKNOWLEDGEMENTS}

The author acknowledge the farmers of the Fazenda Florentino, Marlete Florentino, Eurides Florentino and Nadir de Lima Florentino (in memoriam) for allowing this research on their property.

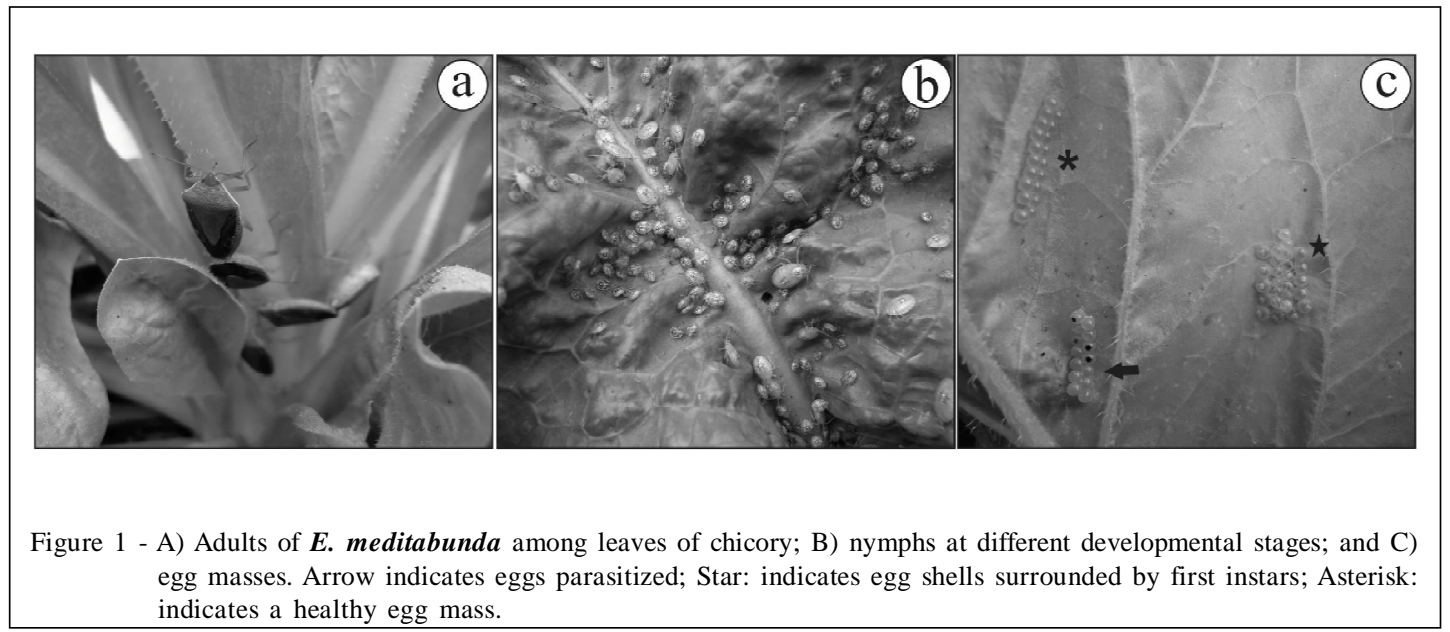

Ciência Rural, v.43, n.1, jan, 2013. 


\section{REFERENCES}

ANDRIOLO, J.L. et al. Tolerance to salinity of chicory plants grown in hydroponics. Ciência Rural, v.38, n.4, p.11421144, 2008. Available from: <http://www.scielo.br/pdf/cr/v38n4/ a38v38n4.pdf $>$. Accessed: Aug. 16, 2012. doi: 10.1590/S010384782008000400038 .

AKSOY, A. Chicory (Cichorium intybus L.): a possible biomonitor of metal pollution. Pakistan Journal of Botany, v.40, p.791-797, 2008. Available from: <http://www.pakbs.org/ pjbot/PDFs/40(2)/PJB40(2)791.pdf>. Accessed: Aug. 16, 2012.

BRASIL. Ministério da Agricultura, Pecuária e Abastecimento. Manual de hortaliças não-convencionais. Ministério da Agricultura, Pecuária e Abastecimento. Secretaria de Desenvolvimento Agropecuário e Cooperativismo. Brasília: Mapa/ ACS, 2010. 92p. Available from: <http://www.abcsem.com.br/ docs/manual_hortalicas_web.pdf>. Accessed: Aug. 16, 2012.

BUZZI, Z.J.; MIYAZAKI, R.D. Entomologia didática. Curitiba: UFPR, 1993. 262p.

COSTA, C.E.; LINK, D. Incidência de percevejos em soja. Revista do Centro de Ciências Rurais, v.4, p.397-400, 1974. Available from: <http://cascavel.ufsm.br/revista_new/ ojs/index.php/RCCCR/article/viewFile/121/122>. Accessed: Aug. $16,2012$.

FALLAH, H.H. et al. The effects of Cynara scolymus L. leaf and Cichorium intybus L. root extracts on carbon tetrachloride induced liver toxicity in rats. Journal of Medicinal Plants, v.10, n.37, p.33-40, 2011. Available from: <http://www.sid.ir/ en/vewssid/j_pdf/82220113704.pdf>. Accessed: Aug. 16, 2012.

FAVERI, L.A. et al. Características produtivas do almeirão em função de espaçamentos. Horticultura Brasileira, v.27, p.29372941, 2009. Available from: <http://www.abhorticultura.com.br/ eventosx/trabalhos/ev_3/A2131_T3488_Comp.pdf>. Accessed: Aug. 16, 2012.

FERNANDES, J.A.M.; CAMPOS, L.D. A new group of species of Edessa Fabricius, 1803 (Hemiptera: Heteroptera: Pentatomidae). Zootaxa, v.3019, p.63-68, 2011. Available from: <http:// www.mapress.com/zootaxa/2011/f/z03019p068f.pdf>. Accessed: Aug. 16, 2012.

GALLO, D. et al. Entomologia agrícola. Piracicaba: FEALQ, 2002. 920p.

GODOI, R.S. et al. Crescimento e produtividade do almeirão em concentrações de $\mathrm{N}$ total contendo $\mathrm{NH} 4+$ na solução nutritiva. Ciência Rural, v.37, n.4, p.1170-1173, 2007. Available from: <http://www.scielo.br/pdf/cr/v37n4/a43v37n4.pdf>. Accessed: Aug. 16, 2012. doi: 10.1590/S0103-84782007000400043.

GOLIN, V. et al. Natural incidence of egg parasitoids of Edessa meditabunda (F.) (Hemiptera: Pentatomidae) on Crotalaria spectabilis in Campo Novo do Parecis, MT, Brazil. Neotropical Entomology, v.40, n.5, p.617-618, 2011. Available from: <http://www.scielo.br/pdf/ne/v40n5/15.pdf>. Accessed: Aug. 16, 2012 . doi: 10.1590/S1519-566X2011000500015.

GONÇALVES, L. et al. Effects of temperature on the development and reproduction of Edessa meditabunda
(Fabricius, 1794) (Hemiptera: Pentatomidae). Acta Biológica Paranaense, v.37, n.1-2, p.111-121, 2008. Available from: <http://ojs.c3sl.ufpr.br/ojs2/index.php/acta/article/view/13248/ 8993>. Accessed: Aug. 16, 2012.

KRINSKI, D.; PELISSARI, T.D. Occurrence of the stinkbug Edessa meditabunda F. (Pentatomidae) in differents cultivars of lettuce Lactuca sativa L. (Asteraceae). Bioscience Journal, v.28, n.4, p.654-659, 2012. Available from: <http:// www.seer.ufu.br/index.php/biosciencejournal/article/view/13462/ 9757>. Accessed: Sep. 03, 2012.

KRINSKI, D. et al. First record of Edessa meditabunda (F.) on lettuce in Mato Grosso State, Brazil. Neotropical Entomology, v.41, n.1, p.79-80, 2012. Available from: <http:// link.springer.com/article/10.1007/s 13744-011-0012-x/ fulltext.html>. Accessed: Oct. 15, 2012. doi: 10.1007/s13744011-0012-x.

LIMA, A.F.; RACCA FILHO, F. Manual de pragas e praguicidas: receituário agronômico. Rio de Janeiro: EDUR, 1996. $818 \mathrm{p}$.

LOURENÇÃO, A.L. et al. Danos de percevejos e de lagartas em cultivares e linhagens de soja de ciclos médio e semi-tardio. Anais da Sociedade Entomológica do Brasil, v.28, p.157167, 1999. Available from: <http://www.scielo.br/pdf/aseb/ v28n1/v28n1a17.pdf>. Accessed: Aug. 16, 2012. doi: 10.1590/ S0301-80591999000100017.

PANIZZI, A.R. Stink bugs on soybean in Northeastern Brazil and a new record on the southern green stink bug, Nezara viridula (L.) (Heteroptera: Pentatomidae). Neotropical Entomology, v.31, p.331-332, 2002. Available from: <http:/ /www.scielo.br/pdf/ne/v31n2/a23v31n2.pdf>. Accessed: Aug. 16, 2012. doi: 10.1590/S1519-566X2002000200023.

PANIZZI, A.R. et al. Stink bugs (Pentatomidae). In: SCHAEFER, C.W.; PANIZZI, A.R. (Ed.). Heteroptera of economic importance. Boca Raton, Florida, USA: CRC, 2000. 828p.

RYDER, E.J. Lettuce, endive e chicory. Cambridge: University, 1998. 208p.

SANDANIELO A.; LUNARDI D.M.C. Coeficientes de cultura da chicória (Chichorium endivia L.). Revista Irriga, v.7, n.2, p.76-80, 2002. Available from: <http://200.145.140.50/ index.php/irriga/article/view/238/143>. Accessed: Aug. 16, 2012.

SILVA, E.J.E. et al. Caracterização do grupo Edessa rufomarginata e descrição de sete novas espécies (Heteroptera, Pentatomidae, Edessinae). Iheringia, Série Zool, v.96, n.3, p.345-362, 2006. Available from: <http://www.scielo.br/pdf/ isz/v96n3/12.pdf>. Accessed: Aug. 16, 2012. doi: 10.1590/ S0073-47212006000300012.

WANG, Q.; CUI, J. Perspectives and utilization technologies of chicory (Cichorium intybus L.): a review. African Journal of Biotechnology, v.10, n.10, p.1966-1977, 2011. Available from: <http://academicjournals.org/ajb/PDF/pdf2011/14Mar/ Wang\%20and\%20Cui.pdf $>$. Accessed: Aug. 16, 2012. doi: $10.5897 /$ AJB 10.587.

WELLS, O.S.; LOY, J.B. Intensive vegetable production with row covers. HortScience, v.20, n.5, p.822-826, 1985. 